\title{
Analisis Pengaruh Islamic Governance terhadap Pengungkapan ISR pada Bank Syariah di Indonesia
}

\author{
Hidayah Fazrin Milenia ${ }^{1}$, Ade Wirman Syafei ${ }^{1}$ \\ ${ }^{1}$ Program Studi Akuntansi, Fakultas Ekonomi dan Bisnis, Universitas Al Azhar Indonesia, \\ Jl. Sisingamangaraja No. 2, Kota Jakarta Selatan, 12110 \\ Penulis untuk Korespondensi/Email: adwirman@uai.ac.id
}

\begin{abstract}
This research aims to analyze the effect of Islamic governance on Islamic social reporting disclosure on Islamic banks in Indonesia from 2016 to 2019. The measurement of ISR in Islamic banks is using the ISR disclosure index rate. The population in this study is Islamic banks in Indonesia listed in OJK. Samples were selected using the purposive sampling method and obtained 44 samples. The data used is secondary data, such as annual reports. Analysis of the data used is the classic assumption test and multiple regression analysis. The result of this study shows that simultaneously sharia supervisory board size, meeting frequency of sharia supervisory board, board of commissioner size, meeting frequency of board of commissioners, board of director size, and meeting frequency of board of directors have a significant effect on ISR disclosure. Based on the partial result of the study, sharia supervisory board size and meeting frequency of board of directors have a significant effect on ISR disclosure. Meanwhile, the other independent variables don't affect ISR disclosure.
\end{abstract}

Keywords: Sharia supervisory board, Board of commissioners, Board of directors, and Islamic social reporting

\begin{abstract}
Abstrak
Penelitian ini bertujuan untuk menganalisis pengaruh Islamic governance terhadap pengungkapan Islamic social reporting pada bank syariah di Indonesia pada tahun 2016 hingga 2019. Pengukuran ISR menggunakan tingkat pengungkapan indeks ISR. Populasi dalam penelitian ini adalah bank syariah yang terdaftar di OJK. Sampel dipilih menggunakan metode purposive sampling dan memperoleh 44 sampel. Data yang digunakan adalah data sekunder, yaitu laporan tahunan. Analisis data yang digunakan adalah uji asumsi klasik, dan agresi linier berganda. Hasil dari penelitian ini menunjukkan bahwa secara simultan ukuran dewan pengawas syariah, frekuensi rapat dewan pengawas syariah, ukuran dewan komisaris, frekuensi rapat dewan komisaris, ukuran dewan direksi, dan frekuensi rapat dewan direksi memiliki pengaruh signifikan terhadap pengungkapan ISR. Berdasarkan hasil analisis secara parsial, ukuran dewan pengawas syariah, dan frekuensi rapat dewan direksi memiliki pengaruh signifikan terhadap pengungkapan ISR. Sementara itu, variabel independen lain tidak memiliki pengaruh signifinkan terhadap pengungkapan ISR.
\end{abstract}

Kata Kunci: Dewan pengawas syariah, Dewan komisaris, Dewan direksi, dan Pengungkapan ISR

\section{PENDAHULUAN}

Pertumbuhan bank syariah di Indonesia dilihat melalui Statistik Perbankan Syariah yang dibuat oleh OJK. Per Januari 2020, industri perbankan syariah terdiri dari 14 Bank Umum Syariah (BUS) dengan total aset sejumlah 346.373 (dalam miliaran rupiah), 20 Unit Usaha Syariah (UUS) dengan total aset sejumlah 168.951 (dalam miliaran rupiah), dan 164 Bank Pembiayaan Rakyat Syariah (BPRS). Hal ini menandakan semakin besar minat masyarakat untuk memakai produk maupun layanan bank syariah. Sehingga anggapan 
terhadap harapan masyarakat pada bank syariah dalam melaksanakan seluruh transaksi sesuai prinsip syariah menjadi bertambah (Baidok \& Septiarini, 2016). Namun tidak hanya berhenti di situ, perkembangan tersebut ditandai dengan prestasi yang ditorehkan pada Global Islamic Finance Report (GIFR) tahun 2019 lalu. Pada Islamic Financial Country Index (IFCI) tahun lalu, Indonesia memperoleh poin 81,93 sehingga menepampati peringkat peringkat pertama. Menurut laporan GIFR tahun 2019, fakta bahwa Indonesia merupakan ekonomi terbesar di OIC-block (Organization of Islamic Cooperation) dalam hal populasi dan PDB, dan dukungan pemerintah terhadap IBF di negara ini, Indonesia dikaitkan sebagai rival yang tak tertandingi dalam hal ini. Namun, prestasi tersebut tidak berbanding lurus dengan pengungkapan informasi sosial yang dilaksanakan perbankan syariah. Penelitian Santoso dan Haq membuktikan bahwa tingkat pengungkapan informasi sosial yang berdasar Islamic Social Reporting Index pada BUS belum optimal, dengan nilai rata-rata $46,39 \%$. (Santoso \& Dhiyaul-Haq, 2017)

Setiap perusahaan, tak terkecuali perusahaan industri keuangan syariah, harus memiliki laporan tanggung jawab sosial. Konsep CSR adalah salah satu inti dari etika bisnis bagi perusahaan. Konsep CSR ini mulai berkembang pada ekonomi syariah, namun indeks CSR belum sepenuhnya memenuhi prinsip-prinsip syariah. Konsep CSR dalam perekonomian syariah didasarkan oleh cara pandang kitabullah, dimana manusia berperan sebagai khalifah atau pemimpin di muka bumi (Kurniawati \& Yaya, 2017). Sebagai pemimpin, manusia harus mempunyai rasa tanggung jawab dalam menjaga semua ciptaan Tuhan, seperti yang termaktub dalam Al Quran surat Al A'raf ayat 74.

Dikarenakan indeks CSR belum mengungkapkan tanggung jawab sosial secara penuh termasuk di dalamnya tentang tema syariah, oleh karena itu sangat diperlukan adanya indeks tersendiri yang mengadopsi prinsip syariah. Melihat hal ini, AAOIFI (Accounting and Auditing Organization for Islamic Financial Institutions) menciptakan Indeks ISR yang menjadi patokan atas pertanggungjawaba sosial perbankan syariah, kemudian penelitian-penelitian selanjutnya memperluas pada item CSR yang semestinya dilakukan pengungkapan oleh perbankan syariah (Othman, Thani, \& Ghani, 2009). Pengungkapan ISR merupakan pengembangan kinerja sosial perusahaan yang mencakup harapan masyarakat, baik dalam perspektif ekonomi maupun spiritual (Haniffa, 2002). Sehingga ISR tidak hanya dapat membantu pengambil keputusan tetapi dapat pula mendorong entitas untuk memenuhi tanggung jawabnya kepada Allah serta masyarakat.

Berbeda dengan CSR yang sifatnya wajib seperti yang diatur Undang-Undang Nomor 40 Tahun 2007 tentang Perseroan Terbatas, namun belum ada dasar hukum yang mewajibkan pengungkapan ISR bagi entitas syariah. Hal ini sejalan dengan beberapa penelitian yang menemukan bahwa pengungkapan ISR pada BUS masih terbilang rendah. Penelitian Santoso dan Haq membuktikan bahwa tingkat pengungkapan informasi sosial yang menggunakan indeks ISR pada BUS belum optimal, dengan nilai rata-rata 46,39\% (Santoso \& Dhiyaul-Haq, 2017). Masalah mengenai rendahnya pengungkapan informasi sosial berlandaskan indeks ISR di tengah prestasi ini dapat dipecahkan dengan menguji hal-hal yang diduga memiliki pengaruh terhadap pengungkapan ISR. Dalam konteks perbankan syariah, kepentingan stakeholder selain finansial adalah kepatuhan syariah (shariah compliance): bank diharapkan selalu beroperasi sesuai dengan aturan prinsip-prinsip syariah. Islamic governance merupakan faktor terdekat yang mempengaruhi kinerja entitas syariah maupun pengungkapan ISR Karena aspek-aspek yang mempengaruhi pengungkapan tersebutlah yang dapat ditingkatkan maupun dijadikan evaluasi bagi BUS.

\section{Teori Legitimasi}

Pfeffer (1981) (Suchman, 1995), menekankan bahwa legitimasi adalah kelarasan antara nilai sosial yang terkait oleh kegiatan (organisasi) dengan norma perilaku yang mampu diterima dalam sistem sosial yang lebih luas. Oleh karena itu, legitimasi adalah salah satu masalah yang krusial bagi perusahaan dikarenakan berkaitan dengan nilai-nilai sosial dan norma-norma perilaku perusahaan dalam berinteraksi secara sosial dengan lingkungan sekitarnya. Legitimasi dianggap sebagai penyamaan persepsi atas perbuatan yang dilakukan oleh perusahaan merupakan 
perbuatansesuai dengan norma maupun kepercayaan masyarakat. Penggunaan teori legitimasi pada penelitian ini mempunyai keterkaitan bahwa dengan pengungkapan tanggung jawab sosial, mengindikasikan adanya harapan akan legitimasi oleh masyarakat. Dilakukannya pengungkapan tanggung jawab sosial oleh perusahaan dapat menyebabkan diterimanya perusahaan tersebut oleh masyarakat.

\section{Shariah Enterprise Theory}

Pada dasarnya Shariah Enterprise Theory merupakan wujud tanggung jawab utama kepada Allah (vertikal) lalu diperinci lagi dengan wujud tanggung jawab kepada manusia serta lingkungannya (horizontal) (Triyuwono, 2001). Dengan kata lain, teori ini menyebutkan bahwasanya Allah merupakan sentra dari segala sesuatu. Menurut Slamet shariah enterprise theory, stakeholder sebagai khalifah diberikan amanah dalam mengelola sumberdaya lalu menyalurkannya pada setiap makhluk di muka bumi dengan adil (Triyuwono, 2001). Perusahaan dapat mememenuhi kewajibannya kepada Allah serta masyarakat melalui ISR.

\section{Islamic Governance}

Penerapan Corporate Governance yang efektif diperlukan guna menjagai hak para stakeholder demi meningkatkan kejujuran, keadilan, serta melindungi kebutuhan manusia sesuai maqashid shariah (Abdullah, 2010). Menurut UU No. 21 2008, BUS dan UUS berkewajiban untuk mengimplementasikan tata kelola yang baik, meliputi prinsip transparansi, akuntabilitas, pertanggungjawaban, profesional, dan kewajaran dalam melaksanakan setiap aktivitas usahanya. Dalam konteks perbankan syariah, kepentingan stakeholder selain finansial ialah kepatuhan syariah (shariah compliance): bank diharapkan selalu beroperasi sesuai aturan syariah. Untuk tujuan tersebut bank syariah menyusun Dewan Pengawas Syariah (DPS). Tentu, selain patuh syariah, para stakeholder tetap berharap kepentingan finansial mereka terlindungi. Sebab itu, untuk memenuhi kepentingan stakeholder secara utuh, bank syariah harus memadukan penerapan prinsip-prinsip CG modern ke dalam kerangka kerja perbankan yang syariah.

\section{Mekanisme Good Corporate Governance}

Berdasarkan KNKG (2006), komposisi suatu entitas syariah yang mencakup RUPS, Dewan
Komisaris, Dewan Pengawas Syariah, Dewan Direksi, dan komite di bawahnya memiliki kedudukan yang vital dalam penerapan corporate governance dengan efisien. Mekanisme GCG merupakan cara, prosedur, aturan guna mewujudkan sistem tata kelola yang baik (Tarigan \& Pratwihatmi, 2017). Mekanisme corporate governance terbagi dua, mekanisme eksternal serta mekanisme internal (Gillan, 2006). Penelitian ini berfokus pada mekanisme internal yang berasal dari struktur, yakni ukuran DPS, dewan komisaris, dan dewan direksi; dan juga mekanisme yang dijalankan oleh struktur tata kelola, yaitu frekuensi rapat DPS, frekuensi rapat dewan komisaris, dan juga frekuensi rapat dewan direksi.

\section{Ukuran Dewan Pengawas Syariah}

Pada bank syariah, kepentingan stakeholder selain finansial adalah kepatuhan syariah (shariah compliance) (Abdullah, 2010). Untuk memenuhi tujuan itu, bank syariah harus membentuk Dewan Pengawas Syariah (DPS) yang di dalamnya terdapat para ulama ahli syariah, yang bertanggungjawab untuk memantai dan memastikan kesesuaian aktivitas usahanya dengan prinsip syariah. Pengangkatan anggota DPS dilakukan melalui RUPS berdasarkan saran MUI. DPS minimal berjumlah dua anggota dan maksimal berjumlah sebanyak $50 \%$ dari dewan direksi.

Ukuran DPS memiliki pengaruh positif signifikan yang berarti semakin banyak jumlah DPS pada suatu BUS maka akan semakin luas pengungkapan ISR (Mukhibad, 2018) (Baidok \& Septiarini, 2016). Pengaruh tersebut bisa saja dikarenakan kewajiban DPS yang dituntut aktif ketika melaksanakan pengawasan, menyatukan data, menelaah dan mengkoreksi setiap findings atas ketidakpatuhan syariah dalam suatu entitas syariah yang diungkapkan dalam suatu laporan sosial yang bersifat syariah. Namun temuan berbeda ditunjukkan oleh penelitian Saputra \& Adityawarman (2016), yaitu ukuran DPS berpengaruh negatif signifikan. Penelitian ini mengindikasikan bahwa semakin banyak jumlah DPS maka pengungkapan ISR yang dilakukan BUS semakin kecil.

\section{Frekuensi Rapat Dewan Pengawas Syariah}

Salah satu mekanisme GCG adalah rapat yang dilaksanakan oleh DPS. Berdasarkan PBI 
11/33/PBI/2009, DPS wajib menyelenggarakan rapat paling sedikit satu kali perbulan. DPS biasanya mendiskusikan perkembangan produk dan juga kegiatan operasi bank dalam rapatnya (Baidok \& Septiarini, 2016).

Penelitian Baidok \& Septiarini (2016) membuktikan bahwa jumlah rapat DPS memiliki pengaruh yang signifikan terhadap pengungkapan ISR. Pengaruh signifikan ini dapat disebabkan oleh semakin intensnya DPS dalam melakukan pertemuan atau rapat.

\section{Ukuran Dewan Komisaris}

Anggota dewan domisaris dipilih, diangkat, dan diberhentikan melalui RUPS degan proses yang transparan. Komposisi Dewan komisaris terdiri dari Komisaris dan Komisaris Independen. Menurut PBI 11/03/PBI/2009, anggota dewan komisaris minimal berjumlah tiga anggota dan maksimal sama dengan jumlah dewan direksi. Banyaknya anggota dewan komisaris pada bank syariah diharapkan dapat menciptakan pengendalian internal dan pengawasan yang semakin baik. Adanya pengawasan yang baik, maka prospek akan pengungkapan ISR akan menjadi lebih luas (Kurniawati \& Yaya, 2017).

Penelitian Mukhibad (2018), dan Yaya \& Kurniawati (2017) menunjukkan bahwa ukuran dewan komisaris berpengaruh secara positif signifikan terhadap pengungkapan ISR sehingga semakin banyak jumlah dewan komisaris maka pengungkapan ISR dapat menjadi lebih luas. Sedangkan penelitian Saputra \& Aditiyawarman (2016) menghasilkan hasil berbeda, dimana ukuran dewan komisaris berpengaruh negatif terhadap pengungkapan ISR. Hal tersebut menandakan bahwa semakin sedikit jumlah dewan komisaris maka pengungkapan ISR yang dilakukan akan semakin luas.

\section{Frekuensi Rapat Dewan Komisaris}

Berdasarkan PBI 11/33/PBI/2009, dewan komisaris berkewajiban untuk mengadakan rapat minimal satu kali dalam dua bulan. Selain itu, dewan komisaris wajib mengadakan rapat bersama dewan direkasi minimal satu kali dalam empat bulan. Rapat tersebut dilaksanakan untuk mendiskusikan dan memantau agar tujuan dan kinerja perusahaan tercapai (Sari \& Helmayunita, 2019).

Penelitian Sari \& Helmayunita (2019) membuktikan bahwa frekuensi rapat dewan komisaris berpengaruh secara signifikan dan positif terhadap pengungkapan ISR yang dilakukan bank syariah. Hal ini menunjukkan bahwa semakin intens dewan komisaris mengadakan rapat, maka tingkat pengungkapan ISR perusahaan akan semakin luas.

\section{Ukuran Dewan Direksi}

Direksi wajib mempunyai fungsi audit internal, manajemen risiko dan komite manajemen risiko, dan kepatuhan dalam menjalankan GCG. Jumlah anggota direksi dalam suatu perusahaan paling sedikit berjumlah tiga anggota (Bank Indonesia, 2009). Adanya dewan direksi pada perusahaan diharapkan dapat mendorong pengelolaan berlandaskan prinsip syariah serta kehati-hatian.

Penelitian Utami (2020) menunjukkan bahwa ukuran dewan direksi berpengaruh positif signifikan terhadap pengungkapan ISR. Sehingga banyaknya jumlah dewan direksi dapat menambah luas pengungkapan ISR.

\section{Frekuensi Rapat Dewan Direksi}

Pada umumnya, dewan direksi di perbankan syariah menyelenggarakan rapat mingguan secara berkala. Keputusan rapat direksi harus diambil berdasarkan musyawarah untuk mufakat. Rapat direksi biasanya membahas mengenai progres terkait dengan pencapaian setiap direktorat yang berguna untuk memastikan bahwa target tersebut telah tercapai, selain itu rapat tersebut dapat menjadi wadah untuk setiap direktorat berkoordinasi.

Penelitian Utami (2020) menunjukkan frekuensi rapat dewan direksi berpengaruh positif signifikan terhadap pengungkapan ISR pada perbankan syariah. Sehingga semakin intens rapat yang dilaksanakan oleh dewan direksi akan menghasilkan pengungkapan ISR yang lebih luas.

\section{Pengungkapan}

Selaku pemilik perusahaan, investor sangat memerlukan informasi keuangan menjadi dasar dalam pengambilan keputusan (Subroto, 2014). Pada umunya, investor tidak mempunyai akses langsung terhadap sumber informasi, sehingga mereka hanya bersandar pada laporan yang diserahkan oleh manajemen yang disajikan dengan segala pengungkapan yang dibutuhkan. Manajemen Apabila 
informasi yang diberikan telah sesuai dengan keperluan para stakeholder, maka manajemen telah memberikan pengungkapan yang diperlukan. Pada dasarnya pengungkapan merupakan penyajian seluruh informasi yang dibutuhkan investor pada laporan keuangan. Pengungkapan terbagi dua, yaitu dapat berupa pengungkapan wajib maupun sukarela.

\section{Perkembangan Bank Syariah di Indonesia}

Otorisasi secara konsisten terus mendukung pertumbuhan industri perbankan syariah nasional. Pada tahun 2016 hingga 2019, bank syariah mengalami perkembangan yang signifikan. Perkembangan tersebut tidak hanya ditunjukkan oleh meningkatnya jumlah aset dan jumlah bank, namun juga ditunjukkan oleh perkembangan industri keuangan syariah Indonesia di kancah global. Aset bank syariah di akhir 2016 tercatat meningkat sebesar Rp40,8 triliun atau tumbuh 19\% dengan jumlah 13 bank. Pada tahun tersebut Indonesia menduduki peringkat enam dalam Global Islamic Financial Report dengan poin 24,21. Pada tahun 2017 tercatat mengalami peningkatan sebesar Rp33,8 triliun atau tumbuh $13 \%$ dengan jumlah 13 bank. Pada tahun tersebut Indonesia menduduki peringkat tujuh dalam GIFR dengan poin 23,98. Pada tahun 2018, aset bank syariah tercatat meningkat sebesar Rp28,7 triliun atau tumbuh 10\% dengan jumlah 14 bank. Pada tahun 2018, Indonesia menduduki peringkat enam GIFR dengan poin 24,13 . pada tahun 2019 , aset bank syariah tercatat sebesar Rp350.4 triliun dengan pertumbuhan sebesar $11 \%$. Pada tahun tersebut, Indonesia untuk pertama kalinya menggeser posisi Malaysia dan meraih posisi pertama dalam GIFR 2019 dengan memperoleh poin sebesar 81,93. Perkembangan yang cukup signifikan tersebut merupakan wujud keberhasilan dari Roadmap Pengembangan Keuangan Syariah Indonesia 2017-2019 oleh OJK.

\section{Islamic Social Reporting}

Dalam teori Islam, nilai-nilai etis dalam pandangan Islam memiliki landasan yang stabil, tidak terpengaruh oleh waktu maupun oleh pandangan teoritis yang lain. Islam dipandang sebagai agama yang relevan bagi setiap manusia, di sepanjang waktu, dan di setiap tempat (Maali, Casson, \& Napier, 2008). Islamic Social Reporting merupakan media untuk menginformasikan tanggung jawab sosial yang telah dilaksanakan entitas syariah. Indeks-indeks tersebut muncul dan diperluas berlandaskan kriteria pelaporan AAOIFI dan selanjutnya diperluas kembali oleh beberapa penelitian. Haniffa dan Hudaib (2002) menyatakan bahwa ISR hendaknya dibangun dalam sebuah framework yang melibatkan tiga dimensi yang saling berhubungan. Tiga dimensi tersebut adalah: memenuhi hak Allah, hak masyarakat, dan hak individu. Dimensi ini harus dijelaskan berlandaskan prinsip syariah yang menyatukannya dalam tujuan ISR yang mencakup dua tujuan baik secara vertikal kepada Allah maupun secara horizontal kepada umat manusia. Pengungkapan ISR merupakan pengembangan kinerja sosial perusahaan yang mencakup harapan masyarakat, baik dalam perspektif ekonomi maupun spiritual. Oleh karena itu, ISR tidak hanya membantu stakeholder, tetapi juga membantu bank syariah pada pemenuhan kewajibannya kepada Allah beserta masyarakat. Untuk mencapai tujuan ISR tersebut, Haniffa dan Hudaib membangun lima tema berlandaskan prinsip syariah. Kelima tema tersebut yaitu keuangan dan investasi, produk, pegawai, masyarakat, dan lingkungan yang kemudian dikembangkan oleh Othman, et al. (2009) menjadi enam tema yaitu: pembiayaan dan investasi, produk dan jasa, karyawan, masyarakat, lingkungan, dan tata kelola organisasi.

\section{METODE PENELITIAN}

\section{Populasi, Sampel, dan Data Penelitian}

Populasi yang menjadi objek dalam penelitian ini yaitu BUS yang terdaftar di Otoritas Jasa Keuangan (OJK) sejak tahun 2016. Penelitian ini menggunakan data sekunder, yaitu laporan tahunan bank syariah tahun 2016 hingga 2019. Objek dalam penelitian ini dipilih menggunakan metode purposive sampling dengan beberapa pertimbangan, yaitu: (1) BUS yang terdaftar di OJK semenjak periode 2016 hingga 2019; (2) BUS yang menerbitkan laporan tahunannya secara konsisten untuk tahun 2016 hingga 2019 di website perusahaan; (3) Laporan tahunan yang diterbitkan menyajikan seluruh informasi terkait variabel dalam penelitian ini.

\section{Metode Analisis Data}

Dalam pengujian hipotesisnya, penelitian ini menggunakan analisis multiple regression. 
Tahap dalam menguji hipotesis yaitu melalui pengujian asumsi klasik, koefisien determinasi, uji $\mathrm{F}$ simultan, lalu uji $\mathrm{T}$ parsial. Sebelum pengujian hipotesis hipotesis, uji asumsi klasik harus dilakukan terlebih dahulu untuk membuktikan bahwa model regresi. Uji asumsi klasik tersebut meliputi uji normalitas, uji multikolinearitas, uji heteroskedastisitas dan uji autokorelasi. Berikut adalah model regresi linier berganda dalam penelitian ini:

$\mathrm{ISR}=\alpha+\beta_{1} \mathrm{DPS}+\beta_{2} \mathrm{RDPS}+\beta_{3} \mathrm{DK}+\beta_{4} \mathrm{RDK}+\beta_{5} \mathrm{DD}+\beta_{6} \mathrm{RDD}+\varepsilon$

\section{Keterangan:}

$\begin{array}{ll}\text { ISR } & \text { : Tingkat Pengungkapan ISR } \\ \alpha & : \text { Regresi yang diterima } \\ \beta i & : \text { Parameter yang diestimasi } \\ \text { DPS } & \text { : Ukuran DPS } \\ \text { RDPS } & \text { : Frekuensi Rapat DPS } \\ \text { DK } & : \text { Ukuran Dewan Komisaris } \\ \text { RDK } & \text { : Frekuensi Rapat Dekom } \\ \text { DD } & : \text { Ukuran Dewan Direksi } \\ \text { RDD } & \text { : Frekuensi Rapat Dewan Direksi } \\ \varepsilon & : \text { Error Term }\end{array}$

\section{Operasional Variabel}

\section{Pengungkapan ISR}

Terdapat enam tema indeks ISR, yaitu pendanaan dan investasi, produk dan jasa, karyawan, sosial, lingkungan, dan tata kelola perusahaan yang kemudian dikembangkan menjadi 48 item oleh Sofyani, et all (2016). Jika item-item tersebut telah diungkapkan seluruhnya, maka nilai maksimal yang dapat dicapai yaitu sebesar 48 yang dihitung dalam satuan persentase.

ISR $=\frac{\text { Pengungkap an yang dilakukan }}{\text { Pengungkap an maksimal }} \times 100 \%$

\section{Ukuran Dewan Pengawas Syariah (DPS)}

Menurut penelitian Baidok \& Septiarini (2016), ukuran DPS diukur melalui penghitungan total anggota DPS. Jumlah DPS dapat dilihat melalui laporan GCG yang tercantum dalam laporan tahunan masing-masing bank syariah.

\section{DPS $=$ Jumlah DPS}

Frekuensi Rapat Dewan Pengawas Syariah (DPS)

DPS wajib menyelenggarakan rapat paling sedikit satu kali setiap bulan Menurut penelitian Baidok \& Septiarini (2016), frekuensi rapat DPS diukur melalui perhitungan jumlah rapat dewan pengawas syariah dalam satu tahun buku yang dapat dilihat melalui laporan GCG yang tercantum dalam laporan tahunan masing-masing bank syariah.

\section{RDPS $=$ Jumlah Rapat DPS}

Ukuran Dewan Komisaris

Anggota dewan komisaris minimal berjumlah tiga anggota dan maksimal sama dengan jumlah anggota dewan direksi. Berdasarkan Penelitian oleh Mukhibad (2018), dan Yaya \& Kurniawati (2017), ukuran dewan komisaris diukur melalui penghitungan total anggota dewan komisaris yang tercantum pada laporan GCG yang tercantum dalam laporan tahunan setiap bank.

\section{DK = Jumlah Dewan Komisaris}

Frekuensi Rapat Dewan Komisaris

Dewan komisaris wajib mengadakan rapat minimal satu kali dalam dua bulan. Rapat tersebut dilaksanakan untuk mendiskusikan dan memastikan bahwa tujuan dan kinerja perusahaan dalam pencapaian strategis, keuangan, akuisisi, divestasi, operasi, manajemen risiko, dan tata kelola dapat tercapai sejalan dengan target perusahaan. Menurut penelitian Sari \& Helmayunita (2019), frekuensi rapat dewan komisaris diukur berdasarkan berapa kali dewan komisaris mengadakan rapat dalam satu tahun buku. Jumlah rapat dewan komisaris dapat diperoleh dari laporan GCG yang tercantum dalam laporan tahunan masing-masing bank syariah.

\section{RDK = Jumlah Rapat Dewan Komisaris}

Ukuran Dewan Direksi

Jumlah anggota direksi pada suatu perusahaan minimal berjumlah tiga anggota. Berdasarkan penelitian Utami (2020), ukuran dewan direksi diukur dengan melihat jumlah dewan direksi pada laporan GCG masing-masing bank. 
DD = Jumlah Dewan Direksi

Frekuensi Rapat Dewan Direksi

Pada umumnya, dewan direksi di perbankan syariah menyelenggarakan rapat mingguan secara berkala. Berdasarkan Penelitian oleh Utami (2020), frekuensi rapat dewan direksi dapat diukur dengan melihat jumlah rapat dewan direksi yang dapat diperoleh dari laporan GCG yang tercantum dalam laporan tahunan masing-masing bank syariah.

\section{$\mathrm{RDD}=$ Frekuensi Rapat Dewan Direksi}

\section{HASIL DAN PEMBAHASAN}

\section{Deskripsi Objek Penelitian}

Objek dalam penelitian ini adalah BUS di Indonesia yang terdaftar di OJK sejak tahun 2016. Data sekunder yang digunakan pada penelitian ini berupa laporan tahunan bank syariah tahun 2016 hingga 2019. BUS yang terdaftar di OJK sejak tahun 2016 hingga 2019 adalah berjumlah 13 bank. Objek dalam penelitian ini dipilih menggunakan metode purposive sampling dengan beberapa pertimbangan tertentu. Dari 13 BUS, sejumlah 11 BUS memenuhi kriteria pengambilan sampel, sehingga sampel yang digunakan dalam penelitian ini berjumlah 11 sampel.

Tabel 1. Deskripsi Objek Penelitian

\begin{tabular}{|l|l|c|c|}
\hline No. & \multicolumn{1}{|c|}{ Kriteria Sampel } & $\begin{array}{c}\text { Tidak Masuk } \\
\text { Kriteria }\end{array}$ & $\begin{array}{c}\text { Masuk } \\
\text { Kriteria }\end{array}$ \\
\hline 1. & $\begin{array}{l}\text { Bank Umum Syariah yang terdaftar di } \\
\text { OJK semenjak periode 2016 hingga } \\
\text { 2019. }\end{array}$ & 0 & 13 \\
\hline 2. & $\begin{array}{l}\text { Bank Umum Syariah yang menerbitan } \\
\text { laporan tahunan secara konsisten } \\
\text { untuk periode 2016 hingga 2019 di } \\
\text { website perusahaan. }\end{array}$ & 0 & 13 \\
\hline 3. & $\begin{array}{l}\text { Laporan tahunan yang diterbitkan } \\
\text { menyajikan seluruh informasi terkait } \\
\text { variabel dalam penelitian ini. }\end{array}$ & 2 & 11 \\
\hline Jumlah Sampel Tiap Periode & \multicolumn{2}{|c|}{11} \\
\hline Periode Penelitian & 4 \\
\hline Total Sampel & \multicolumn{2}{|c|}{44} \\
\hline
\end{tabular}

Sumber: data sekunder diolah, 2020

\section{Uji Koefisien Determinasi $\left(\mathbf{R}^{\mathbf{2}}\right)$}

Uji koefisien determinasi $\left(\mathrm{R}^{2}\right)$ dilakukan guna mengetahui sejauh mana model penelitian ini dapat menjelaskan variasi variabel dependen. Tabel 2 di bawah menunjukkan nilai $\mathrm{R}^{2}$ sebesar 0,351 yang berarti variabel ukuran dewan pengawas syariah, frekuensi rapat dewan pengawas syariah, ukuran dewan komisaris, frekuensi rapat dewan komisaris, ukuran dewan direksi, dan frekuensi rapat dewan direksi memiliki kontribusi dalam menerangkan pengungkapan ISR sebesar $35,1 \%$ dan sisanya dijelaskan oleh variabel lain.

Tabel 2. Hasil Uji Koefisien Determinasi $\left(\mathrm{R}^{2}\right)$

Model Summary

\begin{tabular}{|l|l|r|r|r|}
\hline Model & R & R Square & $\begin{array}{c}\text { Adjusted R } \\
\text { Square }\end{array}$ & $\begin{array}{c}\text { Std. Error of } \\
\text { the Estimate }\end{array}$ \\
\hline 1 & $.592^{\mathrm{a}}$ & .351 & .245 & .07509 \\
\hline
\end{tabular}

a. Predictors: (Constant), Rapat Dewan Direksi, Dewan

Komisaris, Rapat Dewan Komisaris, Rapat Dewan Pengawas

Syariah, Dewan Pengawas Syariah, Dewan Direksi

Sumber: data sekunder diolah, 2020

\section{Uji F (Uji Simultan)}

Uji $F$ simultan digunakan untuk mengetahui apakah ada pengaruh secara simultan antara variabel ukuran dewan pengawas syariah, frekuensi rapat dewan pengawas syariah, ukuran dewan komisaris, frekuensi rapat dewan komisaris, ukuran dewan direksi, dan frekuensi rapat dewan direksi terhadap pengungkapan ISR. Hasil pengujian $F$ simultan pada Tabel 3, menunjukkan nilai signifikansi sebesar 0,010 yang artinya secara bersama-sama variabel independen penelitian ini berpengaruh secara signifikan terhadap pengungkapan ISR.

Tabel 3. Hasil Uji F (Simultan)

\begin{tabular}{|ll|r|r|r|}
\hline Model & & df & F & Sig. \\
\hline 1 & Regression & 6 & 3.332 & $.010^{\circ}$ \\
& Residual & 37 & & \\
& Total & 43 & & \\
\hline
\end{tabular}

Sumber: data sekunder diolah, 2020

Analisis Pengaruh Ukuran DPS terhadap Pengungkapan Islamic Social Reporting $\left(\mathbf{H}_{1}\right)$

Hasil uji $\mathrm{T}$ parsial menunjukkan bahwa variabel ukuran DPS menghasilkan nilai signifikan sejumlah 0,017 dan koefisien sejumlah 0,475 . Artinya variabel ukuran DPS berpengaruh secara positif dan signifikan terhadap pengungkapan ISR. Sehingga hipotesis pertama dapat diterima.

Hal ini dikarenakan DPS bertugas memantau ketaatan bank pada prinsip syariah, meliputi pengawasan yang dilakukan dalam penyaluran dana zakat, infak, dan sedekah yang merupakan wujud dari tanggung jawab sosial bank. Sehingga DPS dapat menekanan para eksekutif dalam memperluas tanggung jawab sosial secara Islami dan juga penungkapannya. 
Penelitian ini memperkuat hasil penelitian Mukhibad (2018) dan Baidok \& Septiarini (2016) yang membuktikan bahwa ukuran DPS memiliki pengaruh positif dan signifikan terhadap pengungkapan ISR.

\section{Analisis Pengaruh Frekuensi Rapat DPS terhadap pengungkapan Islamic Social Reporting $\left(\mathbf{H}_{2}\right)$}

Hasil uji T parsial pada Tabel 4 menunjukkan bahwa frekuensi rapat DPS menghasilkan nilai signifikansi sebesar 0,191. Artinya variabel frekuensi rapat DPSh tidak berpengaruh signifikan terhadap pengungkapan ISR. Sehingga hipotesis kedua tidak dapat ditolak.

Hal tersebut dapat disebabkan rapat yang dilaksanaka dewan pengawas syariah sebagian besar membahas mengenai pemberian opini syariah terhadap portofolio, produk maupun layanan terbaru dari bank syariah. Sehingga banyak sedikitnya frekuensi rapat DPS tidak menjamin luasnya pengungkapan ISR yang dilakukan.

\section{Analisis Pengaruh Ukuran Dewan Komisaris terhadap pengungkapan Islamic Social $\operatorname{Reporting}\left(\mathrm{H}_{3}\right)$ \\ Uji T parsial pada Tabel 4 menunjukkan bahwa ukuran dewan komisaris menghasilkan nilai signifikansi sebesar 0,143. Artinya ukuran dewan komisaris tidak berpengaruh signifikan terhadap pengungkapan ISR, sehingga hipotesis ketiga ditolak.}

Hal tersebut dikarenakan dewan komisaris yang tidak memiliki pengaruh langsung terhadap masalah operasional bank syariah. Selain itu, tanggung jawab dewan komisaris hanya sebatas mengawasi dan menyarankan nasihat terhadap direksi dalam mengelola bank. Berdasarkan tugas dan tanggung jawab dewan komisaris yang dijelaskan pada laporan tahunan sebagian besar bank syariah, diketahui bahwa dewan komisaris tidak memiliki tugas yang berhubungan dengan pengungkapan ISR. Sehingga dewan komisaris belum dapat memberikan nasihat yang berhubungan dengan pengungkapan ISR.

Analisis Pengaruh Frekuensi Rapat Dewan Komisaris terhadap Pengungkapan Islamic Social Reporting $\left(\mathrm{H}_{4}\right)$

Pengaruh frekuensi rapat dewan komisaris menghasilkan nilai signifikansi sebesar 0,544.
Artinya variabel frekuensi rapat dewan komisaris tidak berpengaruh signifikan terhadap pengungkapan ISR. Sehingga hipotesis keempat dalam penelitian ini ditolak.

Hasil penelitian di atas menunjukkan bahwa sedikit banyaknya jumlah rapat dewan komisaris belum dapat memberikan pengaruh terhadap luasnya pengungkapan karena rapat tersebut terfokus pada evaluasi kinerja bank dan juga perubahan struktur tata kelola. Sehingga intensnya rapat yang dilakukan tidak memberikan jaminan bahwa pengawasan terhadap manajemen dalam mengungkapkan ISR dapat belangsung dengan efektif.

\section{Analisis Pengaruh Ukuran Dewan Direksi terhadap Pengungkapan Islamic Social Reporting $\left(\mathrm{H}_{5}\right)$}

Hasil uji $\mathrm{T}$ parsial pada Tabel 4 menunjukkan bahwa ukuran dewan direksi menghasilkan nilai signifikansi 0,244. Artinya variabel ukuran dewan direksi tidak berpengaruh signifikan terhadap pengungkapan ISR, sehingga hipotesis kelima ditolak.

Hasil penelitian ini menunjukkan bahwa sedikit banyaknya dewan direksi tak dapat memberikan pengaruh pada luas pengungkapan ISR yang dilakukan. Sutedi (2014) menjelaskan bahwa terdapat beberapa tren di Indonesia, salah satunya adalah posisi superior yang dimiliki dewan direksi yang menyebabkan direksi enggan membagi kewenangan dan tidak membagiksn informasi yang cukup kepada pihak lain.

\section{Analisis Pengaruh Frekuensi Rapat Dewan Direksi terhadap Pengungkapan Islamic Social Reporting $\left(\mathrm{H}_{6}\right)$}

Hasil uji T parsial pada Tabel 4 menunjukkan bahwa frekuensi rapat dewan direksi menghasilkan nilai signifikansi sebesar 0,047 dengan nilai koefisien sebesar 0,311. Artinya frekuensi rapat dewan direksi berpengaruh positif signifikan terhadap pengungkapan ISR, sehingga hipotesis keenam dapat diterima.

Hasil penelitian ini menunjukkan bahwa semakin intens direksi melakukan rapat akan memperluas pengungkapan ISR yang dilakukan BUS. Hal ini disebabkan bahwa direksi menganggap pelaksanaan dan pengungkapan ISR merupakan suatu bentuk bagian dari kepatuhan syariah dan juga kinerja 
bank syariah. Sehingga rapat yang dilakukan dewan direksi sebagian besar membahas tentang kinerja bank yang termasuk di dalamnya terkait dengan Islamic social reporting.

Penelitian ini memperkuat hasil penelitian Utami (2020), yang membuktikan bahwa frekuensi rapat dewan direksi memiliki pengaruh positif signifikan pada luasnya pengungkapan $I S R$.

Tabel 4. Hasil Simpulan Uji Hipotesis

\begin{tabular}{|c|c|c|c|}
\hline & Hipotesis & Sig & Kesimpulan \\
\hline $\mathrm{H}_{1}$ & $\begin{array}{l}\text { Ukuran dewan pengawas syariah } \\
\text { berpengaruh terhadap pengungkapan } \\
\text { Islamic Social Reporting }\end{array}$ & $0,017^{*}$ & Diterima \\
\hline $\mathrm{H}_{2}$ & $\begin{array}{l}\text { Frekuensi rapat dewan pengawas syariah } \\
\text { berpengaruh terhadap pengungkapan } \\
\text { Islamic Social Reporting }\end{array}$ & $0,191^{*}$ & Ditolak \\
\hline $\mathrm{H}_{3}$ & $\begin{array}{l}\text { Ukuran dewan komisaris berpengaruh } \\
\text { terhadap pengungkapan Islamic Social } \\
\text { Reporting }\end{array}$ & $0,143^{*}$ & Ditolak \\
\hline $\mathrm{H}_{4}$ & $\begin{array}{l}\text { Frekuensi rapat dewan komisaris } \\
\text { berpengaruh terhadap pengungkapan } \\
\text { Islamic Social Reporting }\end{array}$ & $0,544^{*}$ & Ditolak \\
\hline $\mathrm{H}_{5}$ & $\begin{array}{l}\text { Ukuran dewan direksi berpengaruh } \\
\text { terhadap pengungkapan Islamic Social } \\
\text { Reporting }\end{array}$ & $0,244^{*}$ & Ditolak \\
\hline $\mathrm{H}_{6}$ & $\begin{array}{lcr}\text { Frekuensi } & \text { rapat dewan direksi } \\
\text { berpengaruh } & \text { terhadap pengungkapan } \\
\text { Islamic Social Reporting }\end{array}$ & $0,047^{*}$ & Diterima \\
\hline
\end{tabular}

Sumber: data sekunder diolah, 2020

*signifikansi pada $\mathrm{p}<0,05$

\section{KESIMPULAN}

Berdasarkan hasil uji $\mathrm{T}$ parsial maupun hipotesis di atas, dapat ditarik kesimpulan ukuran DPS dan frekuensi rapat dewan direksi memiliki pengaruh positif signifikan terhadap pengungkapan ISR pada BUS yang terdaftar di OJK periode 2016 hingga 2019. Namun penelitian ini tidak mampu membuktikan bahwa terdapat pengaruh signifikan antara frekuensi rapat DPS, ukuran dewan komisaris, frekuensi rapat dewan komisaris, dan ukuran dewan direksi. Dikarenakan penelitian ini memiliki beberapa keterbatasan, maka diharapkan penelitan berikutnya agar dapat memperbanyak sampel yang tidak hanya membatasi pada BUS, tetapi juga dapat memperluas objek penelitian pada UUS maupun BPRS yang terdaftar di OJK, dan dapat pula menggunakan bank syariah negara lain. Selain itu penelitian selanjutnya diharapkan dapat mengeksplorasi bagian-bagian lain dari Islamic Governance, karena Islamic Governance masih memiliki cakupan yang lebih luas dari apa yang dibahas dalam penelitian ini.

\section{REFERENSI}

Abdullah, M. A. (2010). Corporate Governance: Perbankan Syariah di Indonesia. Yogyakarta: Ar-Ruzz Media.

Baidok, W., \& Septiarini, D. F. (2016). Pengaruh Dewan Komisaris, Komposisi Dewan Komisaris Independen, Dewan Pengawas Syariah, Frekuensi Rapat Dewan Komisaris Syariah, Dan Frekuensi Rapat Komite Audit Terhadap Pengungkapan Indeks Islamic Social Reporting Pada Bank Umum Syariah Periode 2010-201. Jurnal Ekonomi Syariah Teori dan Terapan, Vol 3 No 12.

Bank Indonesia. (2009). Peraturan Bank Indonesia Nomor 11/33/PBI/2009 Tentang Pelaksanaan Good Corporate Governance bagi Bank Syariah dan Unit Usaha Syariah. Jakarta: Bank Indonesia.

Gillan, S. L. (2006). Recent Developments in Corporate Governance: An Overview. Journal of Corporate Finance, 12 (381 402).

Haniffa, R. (2002). Social reporting disclosure: An Islamic perspective. Indonesian Management \& Accounting Research, 128 - 146.

Kurniawati, M., \& Yaya, R. (2017). Pengaruh Mekanisme Corporate Governance, Kinerja Keuangan dan Kinerja Lingkungan terhadap Pengungkapan Islamic Social Reporting. journal of Accounting and Investment, Vol 18 No 2.

Maali, B., Casson, p., \& Napier, C. (2008). Social reporting by islamic banks. Abacus, Volume 42 No 2.

Mukhibad, H. (2018). Peran Dewan Pengawas Syariah dalam Pengungkapan Islamic Social Reporting. Jurnal Akuntansi Multiparadigma, Vol 9 No 2.

Othman, R., Thani, A. M., \& Ghani, E. K. (2009). Determinants of Islamic Social Reporting Among Top. Journal of International Studies, Issue 12.

Santoso, A. L., \& Dhiyaul-Haq, Z. M. (2017). Determinan Pengungkapan Islamic Social Reporting pada Bank Umum. Jurnal Dinamika Akuntansi dan Bisnis, Vol 4 No 2.

Sari, M. S., \& Helmayunita, N. (2019). Pengaruh Good Corporate Governance Terhadap Pengungkapan Islamic Social Reporting (Studi Empiris pada Perusahaan yang Terdaftar di Jakarta Islamic Index 
Tahun 2013-2017). Jurnal Eksplorasi Akuntansi, Vol 1 No 2.

Subroto, B. (2014). Pengungkapan Wajib Perusahaan Publik. Malang: UB Press.

Suchman, M. C. (1995). Managing Legitimacy: Strategic and Institutional Approaches. The Academy of Management Review, Vol 20 No 3.

Tarigan, L. R., \& Pratwihatmi, C. Y. (2017). Peran Mekanisme Good Corporate Governance Terhadap Kinerja Keuangan Perbankan yang Terdaftar di Bursa Efek Indonesia. Jurnal Riset Ekonomi dan Bisnis, Vol 10 No 2.
Triyuwono, I. S. (2001). Metafora Zakat dan Shari'ah Enterprise Theory sebagai Konsep Dasar dalam Membentuk Akuntansi Syariah. Jurnal Akuntansi dan Auditing Indonesia, Vol 5 No 2. 